\title{
A Comparison of Pregabalin and Ketamine in Acute Pain Management After Laparoscopic Cholecystectomy
}

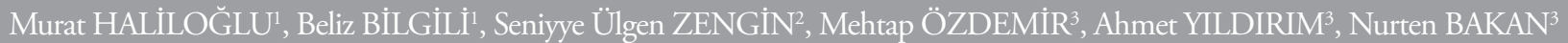 \\ ${ }^{1}$ Department of Anesthesiology and Reanimation, Marmara University School of Medicine, İstanbul, Turkey \\ ${ }^{2}$ Department of Anesthesiology and Reanimation, Bezmialem Vakif University School of Medicine, İstanbul, Turkey \\ ${ }^{3}$ Clinic of Anesthesiology and Reanimation, Ümraniye Training and Research Hospital, İstanbul, Turkey}

\section{ABSTRACT}

Objective: Pregabalin and ketamine are popular analgesic adjuvants for improving perioperative pain management. We designated this double-blind, placebo controlled study to test and compare the preventive effects of pregabalin and ketamine on postoperative pain management after elective laparoscopic cholecystectomy.

Methods: Seventy five patients (18 to 65 years of age) undergoing laparoscopic cholecystectomy were randomly assigned to one of the following 3 groups: control group (group C) received oral placebo capsule $1 \mathrm{~h}$ before surgery and bolus plus intravenous (iv) infusion of saline during surgery; ketamine group (group K) received oral placebo capsule $1 \mathrm{~h}$ before surgery and $0.3 \mathrm{mg} \mathrm{kg}^{-1}$ iv bolus plus $0.05 \mathrm{mg}$ $\mathrm{kg}^{-1} \mathrm{~h}^{-1}$ iv infusion of ketamine during the surgery; pregabalin group (group P) received oral pregabalin $150 \mathrm{mg} 1 \mathrm{~h}$ before surgery and bolus plus iv infusion of saline during surgery. The anesthetic technique was standardized, total tramadol consumption, visual analog scale (VAS), incidence of postoperative nausea and vomiting (PONV), sedation score and complications related to the drugs used in the study were assessed in the postoperative $24 \mathrm{~h}$ period.

Results: Postoperative total tramadol consumption were significantly lower in the pregabalin and ketamine group compared to the group C ( $\mathrm{p}=0.001)$. Tramadol requirement was similar between pregabalin and ketamine groups. At 30 min postoperatively, VAS values were lower in the pregabalin and ketamine groups compared with group $\mathrm{C}(\mathrm{p}=0.001)$. There was no difference between the three groups in the need for supplemental analgesia, incidence of PONV and sedation score $>2$.

Discussion: Pregabalin and ketamine improved postoperative pain control and decreased analgesic consumption after laparoscopic cholecystectomy with a good safety profile without any changes in sedation level or PONV.

Keywords: Postoperative pain, pregabalin, ketamine, laparoscopic cholecystectomy

\section{Introduction}

At present, laparoscopic surgery is the most commonly performed surgery (1). Patients undergoing laparoscopic surgery experience pain, with more severe pain in open surgery $(2,3)$. Despite increased knowledge on pain and pain management, introduction of new pharmacological agents into clinical practice, and technological developments in routes of administration in the last 20 years, $>50 \%$ of the patients still have postoperative pain that is not adequately treated $(1,4-6)$.

Postoperative pain can be controlled more effectively using a multimodal, preventive approach (1). Therefore, opioids are frequently used with non-steroidal anti-inflammatory drugs, local anesthetics, $\alpha_{2}$-adrenergic agonists, gabapentinoids, and ketamines $(7,8)$.

It has been recognized that gabapentinoids (gabapentin and pregabalin), which have entered into clinical practice as anticonvulsant agents, have antinociceptive effects. Although pregabalin has anticonvulsant, antihyperalgesic, and anxiolytic

Cite this article as: Haliloğlu M, Bilgili B, Ülgen Zengin S, Özdemir M, Yıldırım A, Bakan N. A Comparison of Pregabalin and Ketamine in Acute Pain Management After Laparoscopic Cholecystectomy. Bezmialem Science 2017; 5: $162-7$.

$\begin{array}{lll}\text { Address for Correspondence: Murat Haliloğlu; Anesteziyoloji ve Reanimasyon Anabilim Dalı, Marmara Üniversitesi Tip } & \text { Received } & : 31.07 .2016 \\ \text { Fakültesi, istanbul, Türkiye E-mail: mrt.haliloglu@gmail.com } & \text { Accepted } & : 20.09 .2016 \\ \text { OCopyright } 2017 \text { by Bezmialem Vakif University - Available online at www.bezmialemscience.org } & \end{array}$


effects, such as gabapentin, it has a more positive pharmacokinetic profile. Many studies have demonstrated that pregabalin possesses a good analgesic profile for postoperative pain management $(9,10)$.

It is known that the activation of N-methyl-D-aspartate (NMDA) receptors by excitatory neurotransmitters, such as glutamate and aspartate, is effective in central sensitization and pain transmission and modulation. Ketamine is a noncompetitive NMDA receptor antagonist. It decreases depolarization and blocks excitatory transmission.

In some studies evaluating the effect of pregabalin and ketamine on postoperative pain control, they are shown to have preventive analgesic effects $(11,12)$. On the other hand, there are also some studies reporting them to be ineffective $(13,14)$.

The aim of the present study was to investigate the effects of pregabalin or low-dose ketamine, which were applied before laparoscopic cholecystectomy, on early postoperative pain level and analgesic need.

\section{Methods}

The local ethics committee (no.: 78, 28.04.2011; Chief of Ethics Committee: Prof. Dr. Ahmet GÖÇMEN) approved the study. Written informed consent was obtained from the patients. Seventy-five American Society of Anesthesiology III patients aged 18-65 years and planned to be performed elective laparoscopic cholecystectomy were included in the study. Patients who would participate in the study were informed about the patient-controlled analgesia (PCA) device and Visual Analogue Scale (VAS) the night before the operation. Patients who refused to participate in the study; had severe heart, kidney, or liver failure; had a history of chronic use of analgesia, ketamine, and pregabalin or seizure; and had inability and communication difficulty in using the PCA device were excluded from the study.

Patients were randomized via a sealed envelope technique and divided into three groups $(\mathrm{n}=25)$ as the control group (Group C), pregabalin group (Group P), and ketamine group (Group $\mathrm{K})$. All drugs were prepared by the hospital pharmacy, and each patient was given an appropriate code number.

\section{Control group (Group C)}

A placebo capsule was orally given $1 \mathrm{~h}$ before anesthesia induction. After the administration of bolus $5 \mathrm{~mL}$ intravenous (IV) physiological saline solution at induction, infusion of physiological saline solution was continued until the end of operation.

\section{Pregabalin group (Group P)}

A $300 \mathrm{mg}$ pregabalin capsule was orally given $1 \mathrm{~h}$ before anesthesia induction. After the administration of bolus $5 \mathrm{~mL} \mathrm{IV}$ physiological saline solution at induction, infusion of physiological saline solution was continued until the end of operation.

\section{Ketamine group (Group K)}

A placebo capsule was orally given $1 \mathrm{~h}$ before anesthesia induction. At induction, bolus $0.5 \mathrm{mg} / \mathrm{kg}$ ketamine was intravenously given in $5 \mathrm{~mL}$ physiological saline solution. Then, infusion of $10 \mu \mathrm{g} / \mathrm{kg} / \mathrm{min}$ ketamine was continued to be given until the end of operation.

All patients were intramuscularly applied $0.07 \mathrm{mg} / \mathrm{kg}$ midazolam as premedication $45 \mathrm{~min}$ before the operation. The anesthesia technique was standardized in all groups. Anesthesia induction was performed using $2 \mu \mathrm{g} / \mathrm{kg}$ fentanyl, $2 \mathrm{mg} /$ $\mathrm{kg}$ propofol, and $0.6 \mathrm{mg} / \mathrm{kg}$ rocuronium. Following endotracheal intubation, the maintenance of anesthesia was provided using $70 \% \mathrm{~N}_{2} \mathrm{O}$ in oxygen and sevoflurane (end-tidal sevoflurane concentration 1.2-1.3) to retain the bispectral index value $<60$. Ventilation was provided at volume control mode and with the inspiratory:expiratory ratio of $1: 2$, positive end expiratory pressure of $5 \mathrm{~cm} \mathrm{H}_{2} \mathrm{O}$, and tidal volume of $8 \mathrm{~mL} /$ kg (Primus; Draeger ${ }^{\mathrm{TM}}$, Luebeck, Germany). The respiratory rate was adjusted for the end-tidal carbon dioxide value of $30-35 \mathrm{mmHg}$. When blood pressure and heart rate values increased by $>20 \%$ of the baseline value in the intraoperative period, an additional fentanyl dose was administered IV.

All patients were intravenously given $1 \mathrm{mg} / \mathrm{kg}$ tramadol (Contramal $100 \mathrm{mg} / 2 \mathrm{~mL}$; Abdi İbrahim, Istanbul, Turkey) after clipping the cystic artery. After antagonizing the residual neuromuscular block with $0.02 \mathrm{mg} / \mathrm{kg}$ atropine IV and $0.04 \mathrm{mg} /$ $\mathrm{kg}$ neostigmine IV at the end of the operation, patients were extubated while they were completely awake. Patients were started on PCA in the recovery room with bolus $10 \mathrm{mg}$ solution including $5 \mathrm{mg} / \mathrm{mL}$ tramadol and with lock-out time of $10 \mathrm{~min}$. If sufficient analgesia could not be provided despite PCA, $75 \mathrm{mg}$ diclofenac was given intravenously, and these patients were followed up for $24 \mathrm{~h}$ with the following parameters:

1. Postoperative $30 \mathrm{~min}$ and $2,6,12$, and $24 \mathrm{~h}$ VAS scores

2. A 24-hour tramadol consumption and adjuvant analgesic requirement

3. Sedation state with a 4-point scale (15): 0, awake; 1, mildly sedated; 2 , moderately sedated, can be awakened by shaking; 3, deeply sedated, hardly awakened by shaking

4. Complications and side effects.

For calculation of sampling size, we accepted $25 \%$ absolute decrease to be clinically significant in a 24-hour tramadol consumption. Based on pilot studies, a 24-hour tramadol requirement was predicted to be $540 \pm 65 \mathrm{mg}$ in the control group $(\alpha=0.05, \beta=0.2)$. It was calculated that 25 patients per group would be necessary for the study including three groups with equal sizes.

\section{Statistical analysis}

For statistical analyses, NCSS (Number Cruncher Statistical System) 2007\&PASS (Power Analysis and Sample Size) 2008 
Statistical Software (Utah, USA) was used. For evaluation of data obtained from the study, one-way ANOVA test for the comparison of groups in terms of normally distributed parameters and Tukey HSD test for the detection of group leading to difference were employed in addition to descriptive statistical techniques (mean, standard deviation, median, frequency, and ratio). The Kruskal-Wallis test and Mann-Whitney U test were used for the comparison of groups with regard to non-normally distributed parameters and for the detection of the group causing difference, respectively. For comparison of qualitative data, chi-square test was used. A p value of $<0.05$ and $<0.01$ was considered significant.

\section{Results}

The study was conducted on 75 cases. The mean age of the patients was $44.76 \pm 11.93(18-65)$ years. There was no statistically significant difference among the three groups in terms of demographic data $(\mathrm{p}>0.05)$ (Table 1).

Postoperative 30 min VAS scores were significantly lower in Group K and Group T than in Group C ( $\mathrm{p}>0.05)$ (Table 2). At other times, there was no statistically significant difference among the groups.

Total 24-hour tramadol consumption was found to be significantly lower in Group P and Group K than in Group $\mathrm{C}(\mathrm{p}=0.001)$ (Table 3). There was no statistically significant difference among the groups in terms of additional analgesic need ( $>0.05)$ (Table 3).

The first 24-hour sedation score $<2$ was found to be similar in the three groups ( $>0.05)$ (Table 3). The postoperative 24-hour nausea and vomiting rates displayed no difference among the groups $(p>0.05)$ (Table 3). During the postoperative $24 \mathrm{~h}$, other complications (dizziness, visual impairment, nightmare, and hallucination) were not encountered in any patient ( $>0.05$ ) (Table 3).

\section{Discussion}

In the present study, it was observed that $300 \mathrm{mg}$ pregabalin orally given $1 \mathrm{~h}$ before laparoscopic cholecystectomy operation or ketamine infusion administered at a dose of $10 \mu \mathrm{g} /$ $\mathrm{kg} / \mathrm{min}$ during surgery after $0.5 \mathrm{mg} / \mathrm{kg}$ bolus at induction decreased postoperative consumption of analgesia. Furthermore, a 30-minute VAS value was found to be significantly lower in the pregabalin and ketamine groups than in the control group. In the postoperative period, similar pain control was provided despite less consumption of analgesic agent after 30 min.

Patients undergoing laparoscopic surgery experience severe pain particularly between the first 4 and 12 postoperative hours $(2,16,17)$. In these patients, pain is multifactorial. The severity of pain can change depending on the phrenic nerve tension, temperature of insufflated gas, volume of residual
Table 1. Comparison of patients' demographic features among the groups

\begin{tabular}{|c|c|c|c|c|}
\hline & $\begin{array}{r}\text { Grup C } \\
(n=25)\end{array}$ & $\begin{array}{l}\text { Grup P } \\
(n=25)\end{array}$ & $\begin{array}{l}\text { Grup K } \\
(n=25)\end{array}$ & $\mathbf{p}$ \\
\hline Age (year) & $48.36 \pm 11.96$ & $40.84 \pm 13.71$ & $44.36 \pm 10.53$ & 0.165 \\
\hline Height (cm) & $166.48 \pm 6.44$ & $164.80 \pm 10.75$ & $162.28 \pm 6.55$ & 0.261 \\
\hline Weight (kg) & $80.04 \pm 8.60$ & $75.12 \pm 13.46$ & $74.60 \pm 13.37$ & 0.345 \\
\hline ASA score & $1.52 \pm 0.51$ & $1.44 \pm 0.51$ & $1.44 \pm 0.51$ & 0.784 \\
\hline $\begin{array}{l}\text { Duration of } \\
\text { operation }\end{array}$ & $80.88 \pm 39.41$ & $78.24 \pm 30.65$ & $70.68 \pm 20.40$ & 0.357 \\
\hline $\begin{array}{l}\text { Duration of } \\
\text { insufflation }\end{array}$ & $57.12 \pm 37.54$ & $56.92 \pm 27.76$ & $49.68 \pm 17.92$ & 0.573 \\
\hline
\end{tabular}

Values are expressed as mean \pm standard deviation.

ASA: American Society of Anesthesiology.

Table 2. Comparison of VAS values

\begin{tabular}{|l|c|c|c|c|} 
& $\begin{array}{c}\text { Grup C } \\
(\mathbf{n = 2 5 )}\end{array}$ & $\begin{array}{c}\text { Grup P } \\
\mathbf{( n = 2 5 )}\end{array}$ & $\begin{array}{c}\text { Grup K } \\
(\mathbf{n = 2 5 )}\end{array}$ & \multicolumn{1}{c|}{$\mathbf{p}$} \\
\hline VAS 30 min (at rest) & $7.5 \pm 1.6$ & $4.2 \pm 1.2^{\mathrm{a}}$ & $4.3 \pm 1.3^{\mathrm{a}}$ & 0.001 \\
\hline VAS 2 h (at rest) & $2.8 \pm 1.4$ & $2.3 \pm 1.2$ & $2.6 \pm 1.5$ & $>0.05$ \\
\hline VAS 6 h (during activity) & $1.5 \pm 1.4$ & $1.5 \pm 1.1$ & $1.6 \pm 1.3$ & $>0.05$ \\
\hline VAS 12 h (during activity) & $1.7 \pm 1.3$ & $1.4 \pm 1.5$ & $1.5 \pm 0.9$ & $>0.05$ \\
\hline VAS 24 h (during activity) & $1 \pm 1.1$ & $0.9 \pm 0.5$ & $1 \pm 0.6$ & $>0.05$ \\
\hline
\end{tabular}

Values are expressed as mean \pm standard deviation.

VAS: Visual Analogue Scale.

aStatistically significant compared with the control group ( $p=0.001$ ).

Table 3. Total tramadol consumption, adjuvant analgesic dose, and complications

\begin{tabular}{|c|c|c|c|c|}
\hline & $\begin{array}{l}\text { Grup C } \\
(n=25)\end{array}$ & $\begin{array}{l}\text { Grup P } \\
(n=25)\end{array}$ & $\begin{array}{l}\text { Grup K } \\
(n=25)\end{array}$ & $\mathbf{p}$ \\
\hline $\begin{array}{l}\text { Total tramadol } \\
\text { dose (mg) }\end{array}$ & $565 \pm 67.9$ & $401.7 \pm 100.3^{a}$ & $408.3 \pm 105^{a}$ & 0.001 \\
\hline $\begin{array}{l}\text { Total adjuvant } \\
\text { analgesic } \\
\text { (diclofenac) } \\
\text { dose (mg) }\end{array}$ & $18.5 \pm 32.2$ & $12 \pm 25.9$ & $17.5 \pm 32.2$ & $>0.05$ \\
\hline PONV & 4 & 5 & 4 & $>0.05$ \\
\hline Sedation score >2 & 0 & 1 & 0 & $>0.05$ \\
\hline Dizziness & 0 & 0 & 0 & $>0.05$ \\
\hline Visual impairment & 0 & 0 & 0 & $>0.05$ \\
\hline Nightmare & 0 & 0 & 0 & $>0.05$ \\
\hline Hallucination & 0 & 0 & 0 & $>0.05$ \\
\hline \multicolumn{5}{|c|}{$\begin{array}{l}\text { Values are expressed as mean } \pm \text { standard deviation and number. } \\
\text { PONV: postoperative nausea and vomiting. } \\
\text { aStatistically significant compared with the control group } \\
(p=0.001) \text {. }\end{array}$} \\
\hline
\end{tabular}


gas, presence of drain, size of incision, and sociocultural level of the patient (18-20). Moreover, pain associated with ischemia and necrosis can develop in the ligation site after laparoscopic surgery (1). It is difficult to control ischemia-induced pain with traditional low-dose analgesia (21). Insufficiently treated postoperative pain causes deep vein thrombosis, pulmonary embolism, myocardial infarction, pneumonia, and poor wound healing (22).

At present, a multimodal treatment approach combining systemic opioid and non-opioid analgesics is recommended for the control of postoperative pain after laparoscopic surgery (1). Gabapentinoids (gabapentin and pregabalin), the analgesic effects of which were demonstrated, are used in the multimodal treatment approach (23). Pregabalin decreases the release of excitatory pronociceptive neurotransmitters and prevents hyperalgesia and central sensitization (24). In the studies conducted, it has been demonstrated that pregabalin, which is preoperatively used as a single dose, prolongs the length of analgesia more effectively than gabapentin $(25,26)$. In a recent study, gabapentin, which was perioperatively used in patients undergoing cesarean section under spinal anesthesia, led to sedation at a high rate, but its clinically analgesic effectiveness was not reported (27).

Since pregabalin reaches the peak plasma level $1 \mathrm{~h}$ after oral intake, it was applied $1 \mathrm{~h}$ before the operation in our study (28). Baidya et al. (29) reported that pregabalin is effective in the first $6 \mathrm{~h}$, but then its effective plasma level decreases due to its half-life. However, in our study, the exact time when the effect of pregabalin stopped could not be detected because the VAS scores were evaluated at $30 \mathrm{~min}$ and $2,6,12$, and $24 \mathrm{~h}$.

Although many studies have been performed on the use of ketamine for postoperative pain control in the last 15 years, their results are contradictory (30). For effective preventive analgesia, nociceptive stimulation and NMDA receptors should be completely blocked. Therefore, an analgesic agent should be administered continuously during the presence of surgical stimulation. In the studies performed, it has been demonstrated that $0.1-0.5 \mathrm{mg} / \mathrm{kg} / \mathrm{h}$ ketamine infusion administered during intra-abdominal surgery after $0.15-1 \mathrm{mg} /$ $\mathrm{kg}$ IV bolus decreases the need for postoperative opioid (31, 32). Therefore, in our study, $10 \mu \mathrm{g} / \mathrm{kg} / \mathrm{min}$ IV ketamine was applied until the end of the operation after $0.5 \mathrm{mg} / \mathrm{kg}$ IV bolus at induction.

The use of low-dose ketamine $(<2 \mathrm{mg} / \mathrm{kg}$ for intramuscular administration, $<1 \mathrm{mg} / \mathrm{kg}$ for intravenous and epidural administration, and $\leq 20 \mu \mathrm{g} / \mathrm{kg} / \mathrm{min}$ for continuous intravenous administration) is recommended in order to reduce the side effect in clinical practice (33). Plasma concentration of ketamine should be $\geq 100 \mathrm{ng} / \mathrm{mL}$ for an analgesic effect. Following the administration of $1 \mathrm{mg} / \mathrm{kg}$ IV ketamine at induction, the effective plasma concentration is preserved in the first 1-2 h (34). In our study, we believe that the ketamine plasma concentration necessary for an analgesic effect was reached in the first 2 postoperative hours with the application of $10 \mu \mathrm{g} / \mathrm{kg} / \mathrm{min}$ infusion after $0.5 \mathrm{mg} / \mathrm{kg}$ IV bolus. Total tramadol consumption in the first 24 postoperative hours was significantly lower in the ketamine group than in the control group. This suggests that ketamine has a preventive analgesic effect.

It has been demonstrated that low-dose ketamine decreases postoperative nausea and vomiting (PONV) ratio; however, PONV was found to be similar in the three groups in our study (35). We believe that the non-occurrence of PONV at different levels in the ketamine group compared with the other groups might have been associated with the type of surgery.

\section{Study limitations}

The main limitation of the present study is the use of VAS score. Pain can be assessed by using one-dimensional or multidimensional measurement techniques. The VAS, which is a one-dimensional technique, is mostly used for measuring the severity of pain and the effectiveness of treatment (36). However, pain is not a one-dimensional feeling, and it has many features (37). Therefore, a multidimensional technique can be used for the assessment of pain. Since we monitored the first $24 \mathrm{~h}$ in the postoperative period, the effects of lowdose ketamine and pregabalin on the development of chronic pain could not be evaluated.

\section{Conclusion}

In the present study, it was found that the administration of low-dose ketamine or $300 \mathrm{mg}$ pregabalin in patients undergoing laparoscopic cholecystectomy decreased analgesic consumption without increasing the rates of side effects, and it was effective in the 30-minute VAS score. In conclusion, we suggest that low-dose ketamine or $300 \mathrm{mg}$ pregabalin can be safely used as a component of multimodal analgesic treatment, without elevating the incidence of side effects.

Ethics Committee Approval: Ethics committee approval was received for this study from the Ümraniye Training and Research Hospital Local Ethics Comittee (NO: 78, 28.04.2011).

Informed Consent: Written informed consent was obtained from the patients who participated in this study.

Peer-review: Externally peer-reviewed.

Author Contributions: Concept -M.H.; Design -M.H., M.Ö., N.B.; Supervision -M.H., B.B., S.Ü.Z.; Resources -N.B.; Data Collection and/or Processing -M.H., B.B., A.Y.; Analysis and/or Interpretation -M.H., A.Y.; Literature Search -M.H., B.B, M.Ö.; Writing Manuscript -M.H., B.B., M.Ö., S.Ü.Z.; Critical Review -N.B.

Conflict of Interest: No conflict of interest was declared by the authors.

Financial Disclosure: The authors declared that this study has received no financial support. 


\section{References}

1. Sjövall S, Kokki M, Kokki H. Laparoscopic surgery: a narrative review of pharmacotherapy in pain management. Drugs 2015; 75: 1867-89. [CrossRef]

2. Ekstein P, Szold A, Sagie B, Werbin N, Klausner JM, Weinbroum AA. Laparoscopic surgery may be associated with severe pain and high analgesia requirements in the immediate postoperative period. Ann Surg 2006; 243: 41-6. [CrossRef]

3. Lee E, Teeple M, Bagrodia N, Hannallah J, Yazzie NP, Adamas-Rappaport WJ. Postoperative pain assessment and analgesic administration in Native American patients undergoing laparoscopic cholecystectomy. JAMA Surg 2013; 148: 91-3. [CrossRef]

4. Gilron I. Review article: the role of anticonvulsant drugs in postoperative pain management: a bench-to-bedside perspective. Can J Anaesth 2006; 53: 562-71. [CrossRef]

5. Pyati S, Gan TJ. Perioperative pain management. CNS drugs 2007; 21: 185-211. [CrossRef]

6. Apfelbaum JL, Chen C, Mehta SS, Gan TJ. Postoperative pain experience: results from a national survey suggest postoperative pain continues to be undermanaged. Anesth Analg 2003; 97: 534-40. [CrossRef]

7. Arain SR, Ruehlow RM, Uhrich TD, Ebert TJ. The efficacy of dexmedetomidine versus morphine for postoperative analgesia after major inpatient surgery. Anesth Analg 2004; 98: 153-8. [CrossRef]

8. Weinbroum AA. Non-opioid IV adjuvants in the perioperative period: pharmacological and clinical aspects of ketamine and gabapentinoids. Pharmacol Res 2012; 65: 411-29. [CrossRef]

9. Kumar KP, Kulkarni DK, Gurajala I, Gopinath R. Pregabalin versus tramadol for postoperative pain management in patients undergoing lumbar laminectomy: a randomized, doubleblinded, placebo-controlled study. J Pain Res 2013; 6: 471-8. [CrossRef]

10. Jokela R, Ahonen J, Tallgren M, Haanpaa M, Korttila K. A randomized controlled trial of perioperative administration of pregabalin for pain after laparoscopic hysterectomy. Pain 2008; 134: 106-12. [CrossRef]

11. Haliloglu M, Ozdemir M, Uzture N, Cenksoy PO, Bakan N. Perioperative low-dose ketamine improves postoperative analgesia following Cesarean delivery with general anesthesia. J Matern Fetal Neonatal Med 2016; 29: 962-6. [CrossRef]

12. Behdad A, Hosseinpour M, Khorasani P. Preemptive use of ketamine on post operative pain of appendectomy. Korean J Pain 2011; 24: 137-40. [CrossRef]

13. Reza FM, Zahra F, Esmaeel F, Hossein A. Preemptive analgesic effect of ketamine in patients undergoing elective cesarean section. Clin J Pain 2010; 26: 223-6. [CrossRef]

14. Bauchat JR, Higgins N, Wojciechowski KG, McCarthy RJ, Toledo P, Wong CA. Low-dose ketamine with multimodal postcesarean delivery analgesia: a randomized controlled trial. Int J Obstet Anesth 2011; 20: 3-9. [CrossRef]

15. Chia Y-Y, Liu K, Liu Y-C, Chang H-C, Wong C-S. Adding ketamine in a multimodal patient-controlled epidural regimen reduces postoperative pain and analgesic consumption. Anesth Analg 1998; 86: 1245-9. [CrossRef]

16. Joris J, Thiry E, Paris P, Weerts J, Lamy M. Pain after laparoscopic cholecystectomy: characteristics and effect of intraperitoneal bupivacaine. Anesth Analg 1995; 81: 379-84. [CrossRef]
17. Sarac AM, Aktan AÖ, Baykan N, Yegen C, Yalin R. The effect and timing of local anesthesia in laparoscopic cholecystectomy. Surg Laparosc Endosc Percutan Tech 1996; 6: 362-6. [CrossRef]

18. Demco L. Effect of heating and humidifying gas on patients undergoing awake laparoscopy. J Minim Invasive Gynecol 2001; 8:247-51. [CrossRef]

19. Aitola P, Airo I, Kaukinen S, Ylitalo P. Comparison of N2O and $\mathrm{CO} 2$ pneumoperitoneums during laparoscopic cholecystectomy with special reference to postoperative pain. Surg Laparosc Endosc Percutan Tech 1998; 8: 140-4. [CrossRef]

20. Mouton W, Bessell J, Otten K, Maddern G. Pain after laparoscopy. Surg Endosc 1999; 13: 445-8. [CrossRef]

21. Savaris RF, Chicar LL, Cristovam RS, Moraes GS, Miguel OA. Does bupivacaine in laparoscopic ports reduce postsurgery pain in tubal ligation by electrocoagulation? A randomized controlled trial. Contraception 2010; 81: 542-6. [CrossRef]

22. Carr DB, Goudas LC. Acute pain. Lancet 1999; 353: 2051-8.

23. Imani F, Rahimzadeh P. Gabapentinoids: gabapentin and pregabalin for postoperative pain management. Anesth Pain Med 2012; 2: 52-3. [CrossRef]

24. Chizh B, Göhring M, Tröster A, Quartey G, Schmelz M, Koppert W. Effects of oral pregabalin and aprepitant on pain and central sensitization in the electrical hyperalgesia model in human volunteers. Br J Anaesth 2007; 98: 246-54. [CrossRef]

25. Bafna U, Rajarajeshwaran K, Khandelwal M, Verma AP. A comparison of effect of preemptive use of oral gabapentin and pregabalin for acute post-operative pain after surgery under spinal anesthesia. J Anaesthesiol Clin Pharmacol 2014; 30: 373. [CrossRef]

26. Ghai A, Gupta M, Hooda S, Singla D, Wadhera R. A randomized controlled trial to compare pregabalin with gabapentin for postoperative pain in abdominal hysterectomy. Saudi J Anaesth 2011; 5: 252. [CrossRef]

27. Monks DT, Hoppe DW, Downey K, Shah V, Bernstein P, Carvalho JC. A Perioperative Course of Gabapentin Does Not Produce a Clinically Meaningful Improvement in Analgesia after Cesarean DeliveryA Randomized Controlled Trial. Am J Anesthesiol 2015; 123: 320-6. [CrossRef]

28. Ben-Menachem E. Pregabalin pharmacology and its relevance to clinical practice. Epilepsia 2004; 45: 13-8. [CrossRef]

29. Baidya DK, Agarwal A, Khanna P, Arora MK. Pregabalin in acute and chronic pain. J Anaesth Clin Pharmacol 2011; 27: 307. [CrossRef]

30. Elia N, Tramer MR. Ketamine and postoperative pain-a quantitative systematic review of randomised trials. Pain 2005; 113: 61-70. [CrossRef]

31. Zakine J, Samarcq D, Lorne E, Moubarak M, Montravers P, Beloucif $S$, et al. Postoperative ketamine administration decreases morphine consumption in major abdominal surgery: a prospective, randomized, double-blind, controlled study. Anesth Analg 2008; 106: 1856-61. [CrossRef]

32. Guillou N, Tanguy M, Seguin P, Branger B, Campion J-P, Mallédant $Y$. The effects of small-dose ketamine on morphine consumption in surgical intensive care unit patients after major abdominal surgery. Anesth Analg 2003; 97: 843-7. [CrossRef]

33. Becke K, Albrecht S, Schmitz B, Rech D, Koppert W, SCHÜTTLER J, et al. Intraoperative low-dose S-ketamine has no preventive effects on postoperative pain and morphine consumption after major urological surgery in children. Pediatr Anesth 2005; 15: 484-90. [CrossRef] 
34. Kee WDN, Khaw KS, Ma ML, Mainland P-A, Gin T. Postoperative analgesic requirement after cesarean section: a comparison of anesthetic induction with ketamine or thiopental. Anesth Analg1997; 85: 1294-8. [CrossRef]

35. Chandrakantan A, Glass P. Multimodal therapies for postoperative nausea and vomiting, and pain. Br J Anaesth 2011; 107: 27-40. [CrossRef]
36. DeLoach LJ, Higgins MS, Caplan AB, Stiff JL. The visual analog scale in the immediate postoperative period: intrasubject variability and correlation with a numeric scale. Anesth Analg 1998; 86: 102-6.

37. Chapman CR, Casey KL, Dubner R, Foley KM, Gracely RH, Reading AE. Pain measurement: an overview. Pain 1985; 22: $1-31$. 